\title{
RESEARCH PAPER \\ Effects of ractopamine plus amino acids on growth performance, carcass characteristics, meat quality, and ractopamine residues of finishing pigs
}

\author{
Claudia A. Elmes, Ociel H. Bustamante, Fernando G. González, Rafael E. \\ Larraín, and Mónica Gandarillas \\ Departamento de Ciencias Animales, Facultad de Agronomía e Ingeniería Forestal, Pontificia Universidad \\ Católica de Chile, Santiago, Chile.
}

\begin{abstract}
C.A. Elmes, O.H. Bustamante, F.G. González, R.E. Larraín, and M. Gandarillas. 2014. Effects of ractopamine plus amino acids on the growth performance, carcass characteristics, meat quality, and ractopamine residues of finishing pigs. Cien. Inv. Agr. 41(3):297-308. The aim of the study was to evaluate the effects of adding ractopamine (RAC) and amino acids (AA) to the diet on growth performance, carcass characteristics, commercial cuts yield, meat quality and residues in liver and muscle. Ninety-two crossbred castrated pigs $(97.96 \pm 2.32 \mathrm{~kg})$ were randomly assigned to one of two dietary treatments: a Control diet with $0 \mathrm{mg} \mathrm{kg}^{-1}$ of RAC

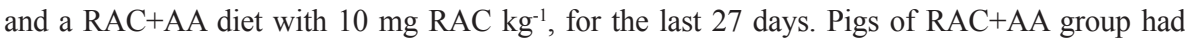
greater average daily gain (ADG), gain to feed ratio $(\mathrm{G}: \mathrm{F})$ and final bodyweight $(\mathrm{P} \leq 0.05)$ and tended to have lower average daily feed intake (ADFI) $(\mathrm{p}=0.084)$ than Control pigs. Carcasses from $\mathrm{RAC}+\mathrm{AA}$ animals were heavier than controls $(\mathrm{P} \leq 0.05)$. Dressing percentage and backfat depth were not affected $(\mathrm{P}>0.05)$ by diet. Weights of head and skin were not different between treatments, but $\mathrm{RAC}+\mathrm{AA}$ pigs had greater weights of boneless center loin, ribs, boneless ham and shoulders, tenderloin, neck, rear shank and trimmings $(\mathrm{P} \leq 0.05)$. The addition of $\mathrm{RAC}+\mathrm{AA}$ did not affect crude protein and water content of loins but tended to reduce ether extract $(\mathrm{P}=0.08)$. Drip loss, $\mathrm{pH}$, and cooking loss in pork were not different. Shear force tended $(\mathrm{P}=0.092)$ to be higher in $\mathrm{RAC}+\mathrm{AA}$. No differences in $L^{*}$ and $b^{*}$ color coordinates were found but $a^{*}$ values were lower in RAC $+\mathrm{AA}$. Hue angle and chroma did not differ. Confidence limits at $90 \%$ were determined for residues in muscle and liver, obtaining values from -2.7 to $3.4 \mu \mathrm{g} \mathrm{kg}{ }^{-1}$ and -6.7 to $10.6 \mu \mathrm{g}$ $\mathrm{kg}^{-1}$, respectively, both below the limits established by Codex Alimentarius. Dietary inclusion

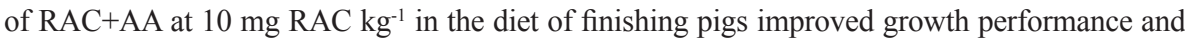
produced heavier carcasses and commercial cuts, had minimal effects in pork characteristics and produced pork and liver with RAC residues below limits from Codex Alimentarius.
\end{abstract}

Key words: Carcass measurements, finishing pigs, meat cuts, meat quality, ractopamine, residues.

\section{Introduction}

One of the main goals for the swine industry is to increase the efficiency of pork production and to

Received December 21, 2014. Accepted August 4, 2014. Corresponding author: mgandari@uc.cl produce lean and quality meat (Schinckel et al., 2003). Ractopamine Hydrochloride (RAC), mar-

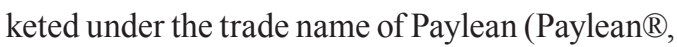
Elanco Animal Health, Greenfield, IN), belongs to a class of drugs known as $\beta$-adrenergic agonists that modulate animal metabolism by increasing 
carcass muscle growth and secondarily decreasing carcass lipid accretion. Hence, the overall effects of RAC addition to the diets of finishing pigs are improving growth rate, improving feed efficiency, producing leaner carcasses and increasing carcass dressing (Moody et al., 2000).

Watkins et al. (1990) showed that by giving increasing concentrations of 5, 10 and $20 \mathrm{ppm}$ of $\mathrm{RAC} \mathrm{kg}^{-1}$ diet, a maximal response for ADG was achieved with 20 ppm of RAC kg-1 diet. Additionally, in a meta-analysis, Apple et al. (2007) showed that the addition of RAC to the diets of finishing pigs improved ADG from $0.85 \mathrm{~kg} \mathrm{~d}^{-1}$ in control animals to $0.95 \mathrm{~kg} \mathrm{~d}^{-1}$ for pigs fed with a $5 \mathrm{mg} \mathrm{RAC} \mathrm{kg-1}$ diet and to $0.94 \mathrm{~kg} \mathrm{~d}^{-1}$ for pigs fed with a $20 \mathrm{mg} \mathrm{RAC} \mathrm{kg}^{-1} \operatorname{diet}(\mathrm{P} \leq 0.001)$. These authors also demonstrated an improvement in feed efficiency (G:F) $(\mathrm{P} \leq 0.001)$ from 0.30 to $0.33,0.34$ and 0.35 for pigs fed with a $0,5,10$ and $20 \mathrm{mg}$ RAC kg-1 diet, respectively. Likewise, Schinckel et al. (2002) showed that in high-lean-gain pigs, a $5 \mathrm{mg} \mathrm{RAC} \mathrm{kg}{ }^{-1}$ diet was effective to achieve a substantial improvement of pig performance. Thus, regardless of the RAC concentration used $(5,10$ and $20 \mathrm{mg} \mathrm{kg}^{-1}$ diet), pigs gain lean tissue faster and more efficiently when RAC is included in the diet. Furthermore, the improvements in growth performance after RAC supplementation in the diets of finishing pigs usually improved carcass weight and dressing percentage (Stoller et al., 2003; Mimbs et al., 2005; Carr et al., 2009) and have minimal effects on meat quality (Armstrong et al., 2004; Fernández- Dueñas et al., 2008; Kutzler et al., 2011).

The Food and Drug Administration (FDA) approved RAC use in finishing pigs in December 1999 as a feed additive for the last 20.4 to $40.8 \mathrm{~kg}$ of live weight gain before slaughter. Most of the studies available on RAC use growth performance traits (Aalhus et al., 1990; Barker et al., 2005; Ross et al., 2011) or carcass measurements, meat quality and sensory attributes (Fernández-Dueñas, 2008; Kutzler et al., 2011), but few studies have reported tissue residue concentrations (i.e., muscle and liver). Some studies have focused on comparing techniques to quantify residues (Shishani et al., 2003; Qiang et al., 2007; Sakai et al, 2007), but to our knowledge, there are no complete studies using RAC that reported live animal performance, carcass and meat characteristics, and residue concentrations in target tissues. Thus, the objective of this study was to investigate the effects of the addition of RAC plus amino acids on growth performance, carcass characteristics, cuts yield, meat quality, sensory attributes and residues in liver and muscle of finishing pigs.

\section{Materials and methods}

This study was performed at the Center for Research, Technological Innovation and Training for the Pork Industry (CICAP) in Pirque, Región Metropolitana, Chile. Because the use of $\beta$-adrenergic agonists as feed supplements is prohibited in Chile, the authorities of the Ministry of Agriculture (through the Agricultural and Livestock Service, SAG) authorized the importation and use of Paylean 20® (Elanco Animal Health, Greenfield, IN) for research purposes (Extent Resolution $\mathrm{N}^{\mathrm{o}} 000044$ from Agricultural and Livestock Service, January $19^{\text {th }}, 2012$ ). Animals received care in accordance with the Guide for the Care and Use of Laboratory Animals (National Institute of Animal Science Animal Care Committee). Carcasses from RAC-fed animals were removed after slaughter from the food supply chain.

\section{Animals and treatments}

All animals were housed within a single barn equipped with 16 pens with concrete floors. Each pen $(2.5 \times 2.0 \mathrm{~m})$ had a tube type wet-dry feeder (Rotechna ${ }^{\circledR}$, Spain), and animals had ad libitum access to both feed and fresh water. A total of 92 crossbred male castrated Pig Improvement Company (PIC) pigs [PB $337 \times$ GP 1050] -a high lean-gain genetic cross- that were 152 days old with initial weights of $97.96 \pm 2.32 \mathrm{~kg}$ were randomly 
assigned into one of two dietary treatments. Each treatment contained 8 pens with 5-6 pigs per pen (pen $=$ experimental unit). Dietary treatments were a control diet with $0 \mathrm{mg} \mathrm{kg}^{-1}$ of RAC and a RAC $+\operatorname{amino}$ acid (AA) diet. The RAC + AA diet had $10 \mathrm{mg} \mathrm{RAC} \mathrm{kg}{ }^{-1}$ added to the diet and a higher content of amino acids, as indicated in Table 1. Diets were based on corn and soybean-meal and were iso-energetics. Both diets were formulated to meet or exceed the nutritional recommendations of NRC (2012). As mentioned above, diets were different in protein and amino acid content, and amino acids were added using soybean meal plus synthetic amino acids (L-Lysine, L-Threonine and DL-Methionine; Table 2), as recommended by the manufacturer of RAC and used by the industry. The control diet was formulated to have $13.42 \% \mathrm{CP}$ and $0.73 \%$ standardized ileal digestible (SID) Lysine, as recommended by PIC for maximal growth, and the RAC+AA diet contained $16.49 \% \mathrm{CP}$ and $0.91 \%$ SID Lysine. Diets containing RAC must contain at least 16\% CP (NRC, 2012). Vitamins and minerals used in the experiment were formulated to meet or exceed the nutritional requirements of finishing pigs according to NRC (2012) (Table 1). The experimental period lasted 27 days before slaughter.

Table 1. Composition of experimental diets, as-fed basis.

\begin{tabular}{|c|c|c|}
\hline Items & Control & $\mathrm{RAC}+\mathrm{AA}^{1}$ \\
\hline \multicolumn{3}{|l|}{ Ingredients (\%) } \\
\hline Corn & 77.20 & 68.9 \\
\hline Wheat middlings & 6.00 & 6.00 \\
\hline Soybean meal & 12.60 & 20.3 \\
\hline Poultry oil & 1.50 & 2.20 \\
\hline L-Lysine sulphate $51 \%{ }^{2}$ & 0.05 & 0.05 \\
\hline Threonine $98.5 \%$ & 0.76 & 0.92 \\
\hline Methionine $84 \%$ & 0.34 & 0.75 \\
\hline Calcium carbonate & 9.50 & 9.20 \\
\hline Salt & 6.00 & 6.00 \\
\hline Dicalcium Phosphate & 3.00 & 1.30 \\
\hline Ronozyme P5000 ${ }^{3}$ & 0.10 & 0.10 \\
\hline Ronozyme blend $<20 \%{ }^{4}$ & 1.00 & 1.00 \\
\hline Copper sulphate & 0.50 & 0.50 \\
\hline Etoxiquine & 0.20 & 0.20 \\
\hline Vitamin + mineral premix ${ }^{5}$ & 1.00 & 1.00 \\
\hline \multicolumn{3}{|l|}{ Chemical composition } \\
\hline Dry Matter (\%) & 89.38 & 89.42 \\
\hline Moisture (\%) & 10.62 & 10.58 \\
\hline Ash (\%) & 4.84 & 4.73 \\
\hline Crude protein (\%) & 14.45 & 17.38 \\
\hline Crude fiber (\%) & 3.93 & 4.46 \\
\hline Ether extract (\%) & 5.01 & 5.88 \\
\hline
\end{tabular}

${ }^{1} \mathrm{RAC}+\mathrm{AA}$ : contained $10 \mathrm{mg} \mathrm{RAC} \mathrm{\textrm {kg } ^ { - 1 }}$ of diet and added amino acids.

${ }^{2}$ L-Lysine at $51 \%$.

${ }^{3}$ Ronozyme ${ }^{\circledR}$ (CT) P5000 phytase provided by DSM Nutritional Products.

${ }^{4}$ Ronozyme blend $<20 \%$ carbohydrase complex ( $\beta$-glucanases, xylanases, pectinases, hemicellulases) provided by DSM Nutritional Products.

${ }^{5}$ Vitamin+mineral premix per kilogram of the diet provided by premix: Vitamin A, 4,840,000 IU; Vitamin D3, 990,000 IU; Vitamin E, 22,500 IU; Vitamin K3, $2.20 \mathrm{~g}$; Riboflavin, $4.40 \mathrm{~g}$; Vitamin B12, 22.00 mg; d-Pantothenic calcium, 14.30 g; Niacin, 22.00 g, Cu, 10.00 g; Fe, 65.00 g; Mn, $25.00 \mathrm{~g}$; Se, $300.00 \mathrm{mg}$; I, $350.00 \mathrm{mg}$; Zn, $70.00 \mathrm{~g}$; Antioxidant, $2.50 \mathrm{~g}$. 
Table 2. Amino acid composition of experimental diets (as-fed basis).

\begin{tabular}{lcc}
\hline Items & Control & RAC+AA ${ }^{1}$ \\
\hline Lysine total (\%) & 0.84 & 1.05 \\
Available 2 lysine (\%) & 0.73 & 0.91 \\
Available methionine (\%) & 0.22 & 0.28 \\
Available threonine (\%) & 0.48 & 0.59 \\
Available tryptophan (\%) & 0.12 & 0.16 \\
Available valine (\%) & 0.50 & 0.63 \\
Available isoleucine (\%) & 0.42 & 0.54 \\
\hline
\end{tabular}

${ }^{1} \mathrm{RAC}+\mathrm{AA}$ : contained $10 \mathrm{mg} \mathrm{RAC} \mathrm{kg}-1$ of diet and added amino acids.

${ }^{2}$ Availability of amino acids was estimated by FT-NIR spectrophotometry (www.adisseo.com).

\section{Growth performance}

The pigs and feeders were weighed at the beginning (d0) and at the end of the study (d27) to determine average daily gain (ADG, $\mathrm{kg} \mathrm{d}^{-1}$ ), average daily feed intake (ADFI, $\mathrm{kg} \mathrm{d}^{-1}$ ) and the ratio of gain to feed (G:F). Pig weights and feed intakes were recorded using an electronic scale (PESATRONIC, MECO20014575PA-21X, Ohause, Brooklyn NY, USA).

\section{Transport, slaughter and carcass measurements}

At day 27, animals were transported approximated $110 \mathrm{~km}$ during the summer to the slaughterhouse at the city of Rancagua, Chile. Upon arrival, animals of each treatment were housed in two separate pens. Sixteen hours after arrival, pigs were electrically stunned, exsanguinated, scalded, and eviscerated, and each carcass was split into left and right sides. The slaughter procedure followed the packing plant's protocol, which was in accordance with the legal procedure for commercial pigs according to Chilean Meat Law 19,162. Individual hot carcass weight (HCW) was immediately registered, as was backfat depth on the midline at the $10^{\text {th }}$ rib through the ribbed carcass. After 24 hours of chilling, cool carcass weight $(\mathrm{CCW})$ was measured, and pork cuts were fabricated. Cuts were produced based on Chilean industry standard and are schematically presented in Figure 1. The following cuts from the left side of the carcass were weighed using an electronic balance scale (PRECISION, BL simplex $60 \mathrm{Kg} * 20 \mathrm{G})$ : lomo de centro (boneless center loin), lomo vetado (boneless neck), costillar (ribs), filete (tenderloin), pulpa de pierna (boneless ham), pulpa de paleta (boneless shoulder), cabeza (head), pernil de pierna (rear shank), recortes (trimmings) and plancha (skin). Chilean commercial cuts are described by Luengo and Antmann (1999).

\section{Meat quality}

For evaluation of pork quality attributes, 16 loins from each treatment were sampled and transported to the Meat Laboratory at Pontificia Universidad Católica de Chile. Subjective marbling (NPPC, 1999) and objective color of loin chops were evaluated at the $10^{\text {th }}$ rib on the seventh day after slaughter. Objective color was measured with a chromameter (Minolta CR-400, Osaka, Japan) at three different locations in each loin sample. Data were collected in CIE $L^{*} a^{*} b^{*}$ color space. Lightness $\left(L^{*}\right)$, redness $\left(a^{*}\right)$, yellowness $\left(b^{*}\right)$, chroma

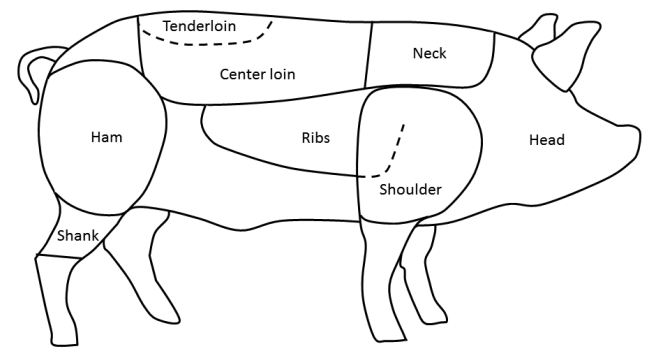

Figure 1. Schematic representation of evaluated pork cuts. 
[or color saturation, $\left(\mathrm{a}^{* 2}+\mathrm{b}^{* 2}\right)^{0.5}$ ], and hue angle [arctangent $\left.\left(\mathrm{b}^{*} / \mathrm{a}^{*}\right) \times 360 \%(2 \times 3.14)\right]$ were evaluated using a $1 \mathrm{~cm}$ aperture, illuminant D65 and a $0^{\circ}$ observer. Chop collection began anterior to the $10^{\text {th }}$ rib and included a $2 \mathrm{~cm}$-thick chop for measuring drip and purge loss, a $2 \mathrm{~cm}$-thick chop for proximate analysis, and a $2 \mathrm{~cm}$-thick chop for Warner-Bratzler shear, cooking loss, and $\mathrm{pH}$. Proximate analysis was conducted according to the AOAC (1984). The final $\mathrm{pH}$ was measured on the seventh day after slaughter using a spear tip electrode (Mettler Toledo AG 8603, Schwerzenbach, Switzerland). Cooking loss was determined 8 days post mortem by measuring weight loss after cooking to $71^{\circ} \mathrm{C}$ in an open-hearth electric broiler (MGF 4620, Magefesa, Spain). Warner-Bratzler shear measurements were based on AMSA (1995).

\section{Evaluation of $R A C$ residues in liver and muscle}

At the packing plant, 6 loin and 6 liver samples were randomly taken from $\mathrm{RAC}+\mathrm{AA}$ animals, as were 3 loin and 3 liver samples from the control pigs. The samples were frozen at $20^{\circ} \mathrm{C}$ and delivered to Andes Control Laboratory (Santiago, Chile) for RAC residue quantification. RAC residues were measured using high performance liquid chromatography with tandem mass spectrometry (LC/MS/MS) as described by Blanca et al. (2005).

\section{Statistical analysis}

Animals were assigned to treatments using a complete randomized design. Statistical analysis was performed using the general linear model (GLM) procedure from the Statistical Analysis Systems Institute software package (SAS, Institute Inc., Cary, NC, USA) for all variables other than marbling score. The pen was considered the experimental unit. We considered significant differences when one-way ANOVA indicated a P-value $\leq 0.05$, whereas $\mathrm{P}$-values between 0.05 and 0.10 were considered to indicate a tendency for differences. Initial weight was considered as a covariance of pig weights. The marbling score was analyzed using the two sample non-parametric test of Wilcoxon (t approximation). For the RAC residues analysis in liver and muscle, a confidence interval was set at $90 \%$ for comparison with limits set by Codex Alimentarius (2011).

\section{Results and discussion}

\section{Growth performance}

The effects of $\mathrm{RAC}+\mathrm{AA}$ on growth performance of finishing pigs are presented in Table 3. Average daily gain was $18.42 \%$ greater in pigs from the RAC +AA treatment compared with control pigs, and RAC+AA pigs were $5.07 \%$ heavier at the end of the study compared with control pigs. The feed efficiency, measured as G:F, was $22.58 \%$ greater in $\mathrm{RAC}+\mathrm{AA}$ pigs. These results are consistent with the results from other authors (Apple et al., 2004; See et al., 2004; Rikard- Bell et al., 2009). Barker et al. (2005) reported an improvement of $16 \%$ in ADG with a $10 \mathrm{mg} \mathrm{RAC} \mathrm{kg}^{-1}$ diet, whereas Dunshea (1993) obtained 21\% greater ADG with a $20 \mathrm{mg} \mathrm{RAC} \mathrm{kg}^{-1}$ diet. By contrast, Rikard- Bell et al. (2009) and Mimbs et al. (2005) found no

Table 3. Effects of the addition of ractopamine plus amino acids in the diet on growth performance and intake in finishing pigs.

\begin{tabular}{lcccc}
\hline & Control & $\mathrm{RAC}+\mathrm{AA}^{1}$ & $\mathrm{SE}^{2}$ & P-value \\
\hline Initial weight $(\mathrm{kg})$ & 97.62 & 98.29 & 0.58 & 0.583 \\
Final weight $(\mathrm{kg})$ & 128.33 & 134.84 & 1.21 & 0.003 \\
ADG $\left(\mathrm{kg} \mathrm{d}^{-1}\right)$ & 1.14 & 1.35 & 0.04 & 0.001 \\
ADFI $\left(\mathrm{kg} \mathrm{d}^{-1}\right)$ & 3.68 & 3.54 & 0.04 & 0.084 \\
Feed efficiency & 0.31 & 0.38 & 0.01 & $<0.001$ \\
\hline
\end{tabular}

${ }^{1} \mathrm{RAC}+\mathrm{AA}$ : contained $10 \mathrm{mg} \mathrm{RAC} \mathrm{kg}{ }^{-1}$ of diet and added amino acids.

${ }^{2}$ Pooled SE from ANOVA. 
effect of RAC on ADG using 5 and $10 \mathrm{mg} \mathrm{kg}^{-1}$ diets, respectively.

There was a tendency $(\mathrm{P}=0.084)$ for decreased ADFI in the RAC+AA group, which is similar to results observed by Armstrong et al. (2004). However, some authors reported an increased

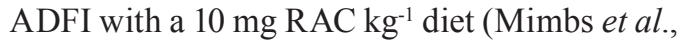
2005) and even with a $5 \mathrm{mg} \mathrm{RAC} \mathrm{kg}^{-1}$ diet (RikardBell et al., 2009). In our experiment, we used a $10 \mathrm{mg} \mathrm{RAC} \mathrm{kg}^{-1}$ diet throughout the experimental period (27 days), but it is also common to find studies that used a step-up feeding program that switches from an initial concentration of $5 \mathrm{mg}$ $\mathrm{kg}^{-1}$ in the first 14 days to $10 \mathrm{mg} \mathrm{kg}^{-1}$ in the final 14 days. Regardless of the feeding program used, See et al. (2004) observed that either a step-up or a constant feeding program resulted in no differences in ADFI.

Improvement in weight gain was accomplished when extra lysine and amino acids were supplied in the diet with RAC (Apple et al., 2004; Carr et al., 2009). The recommended use by the manufacturer includes both RAC and an increased amount of AA in the diet, and this is also the common practice used by producers. However, increased weight gain was observed up to $1.15 \%$ total lysine in the diet, independent of RAC concentration (Pérez et al., 2005). The RAC+AA diet contained $1.05 \%$ total lysine, compared to $0.84 \%$ total lysine in the control diet. Thus, some improvement in ADG was expected even without the addition of RAC. Pérez et al. (2005) and Webster et al. (2007) found no significant interaction between RAC and lysine levels, but other authors have observed contrasting results (Armstrong et al., 2004; Carr et al., 2005).

Greater improvement in feed efficiency was reported when RAC and amino acids were added to the finishing diets (Mimbs et al., 2005; Apple et al., 2007; Groesbeck et al., 2007) independent of the supplementation period but dependent on the RAC concentration in the diet. We observed a $22.58 \%$ greater feed efficiency in the RAC+AA pigs vs. the control pigs, which is greater than the results reported by Barker et al. (2005), who showed a $16.13 \%$ improvement using an identical RAC concentration (10 $\mathrm{mg} \mathrm{kg}^{-1}$ diet). Differences might be attributed to a shorter time of RAC supplementation (21 vs. 27 days), as shown in Barker et al. (2005), although it is known that the response to RAC decreases with duration of use. Edmonds and Baker (2010) also observed greater feed efficiency with increased protein and lysine concentrations in diets containing RAC, whereas Ross et al. (2011) found no effect on the same parameter when RAC was added without any extra protein and lysine.

\section{Carcass measurements}

The effects of $\mathrm{RAC}+\mathrm{AA}$ on carcass measurements are shown in Table 4. Carcasses from $\mathrm{RAC}+\mathrm{AA}$ pigs had greater $\mathrm{HCW}$ and $\mathrm{CCW}$ than control pigs. Similar results were reported by See et al. (2004) and Carr et al. (2009). Dressing percentage was not affected by RAC+AA, and this observation is consistent with the results of Marchant-Forde et al. (2003), despite the fact that they used a 20 mg RAC kg-1 diet. Nevertheless, other authors reported increased dressing percentage in pigs fed diets with 5 to $20 \mathrm{mg} \mathrm{RAC} \mathrm{kg}^{-1}$ (Weber et al., 2006; Fernández-Dueñas et al., 2008; Agostini et al., 2011; Kutzler et al., 2011).

When comparing backfat depth at the $10^{\text {th }} \mathrm{rib}$, our results indicated that there were no significant differences between $\mathrm{RAC}+\mathrm{AA}$ fed pigs and control pigs, which is consistent with the results of Armstrong et al. (2004), Xiong et al. (2006), and Kutzler et al. (2011). However, See et al. (2004), Carr et al. (2005) and Fernández- Dueñas et al. (2008) observed that there was a significant reduction in backfat depth in RAC fed pigs.

The effects of RAC+AA on commercial cuts yield are presented in Table 4 . We observed no differences in head and skin weight between treatments, but all the remaining cuts from the $\mathrm{RAC}+\mathrm{AA}$ 
Table 4. Effects of ractopamine plus amino acids addition on carcass characteristics from pigs.

\begin{tabular}{lcccc}
\hline & Control & RAC+AA & SE $^{2}$ & P-value \\
\hline Hot carcass weight (kg) & 102.81 & 108.62 & 0.98 & $<0.001$ \\
Carcass dressing (\%) & 80.10 & 80.70 & 0.82 & 0.115 \\
Cold carcass weight (kg) & 100.28 & 106.06 & 0.97 & 0.001 \\
Backfat depth (mm) & 27.65 & 27.52 & 0.36 & 0.621 \\
Head (kg) & 7.60 & 7.74 & 0.06 & 0.217 \\
Boneless center loin (kg) & 3.67 & 3.92 & 0.05 & 0.021 \\
Ribs (kg) & 7.23 & 7.60 & 0.08 & 0.021 \\
Boneless ham (kg) & 8.54 & 9.69 & 0.19 & $<0.001$ \\
Boneless shoulder (kg) & 4.00 & 4.49 & 0.08 & $<0.001$ \\
Tenderloin (kg) & 0.53 & 0.61 & 0.01 & $<0.001$ \\
Neck (kg) & 1.92 & 2.02 & 0.02 & 0.008 \\
Rear shank (kg) & 2.59 & 2.71 & 0.03 & 0.033 \\
Trimmings (kg) & 5.75 & 6.10 & 0.07 & 0.003 \\
Skin (kg) & 10.30 & 10.42 & 0.10 & 0.554 \\
Total (kg) & 96.66 & 102.84 & 0.97 & $<0.001$ \\
\hline
\end{tabular}

${ }^{1} \mathrm{RAC}+\mathrm{AA}$ : contained $10 \mathrm{mg} \mathrm{RAC} \mathrm{kg}{ }^{-1}$ of diet and added amino acids. ${ }^{2}$ Pooled SE from ANOVA.

group were heavier than those from the control group. See et al. (2004), Fernández- Dueñas et al. (2008) and Kutzler et al. (2011) observed that greater cutting yields in pigs were mainly caused by RAC addition instead of higher dietary protein levels, which is consistent with Carr et al. (2009), who observed increased cutting yields by adding $\mathrm{RAC}$ to the diet without increasing protein concentration in the diet.

\section{Meat quality}

The effects of RAC+AA on the chemical composition and meat quality parameters are presented in Table 5. RAC+AA addition did not affect the crude protein and dry matter content of loin muscle samples. By contrast, Dunshea et al. (1993) and Carr et al. (2009) found greater crude protein content in loin muscle samples of RAC supplemented animals compared to controls on a dry matter basis.

We observed a tendency $(\mathrm{p}=0.082)$ for a reduction in ether extract in the $\mathrm{RAC}+\mathrm{AA}$ pigs compared to the control pigs. The magnitude of the difference was greater than the difference reported by Dunshea et al. (1993) (18.25\% vs. 8\% in ether extract in pork from RAC fed animals). Additionally, Weber et al. (2006) found a reduction in Longissimus Muscle (LM) lipid content, from 2.4 to 1.92 , in control vs. RAC fed animals. In our study, drip loss, $\mathrm{pH}$, and cooking loss were not different between treatments. Kutzler et al. (2011) found that water holding capacity was $0.57 \%$ higher when RAC was added to a $6.2 \mathrm{mg}$ $\mathrm{kg}^{-1}$ diet. We observed a tendency $(\mathrm{P}=0.092)$ for higher Warner Bratzler shear in RAC+AA loins, which is consistent with the differences observed by Xiong et al. (2006).

There were no treatment differences in $L^{*}$ and $b^{*}$ color coordinates between treatments, but $a^{*}$ was lower in RAC+AA pork. Additionally, hue angle and chroma did not differ between treatments. The effects of RAC on pork color are not consistent. Armstrong et al. (2004) and Xiong et al. (2006) observed no differences in $L^{*}$, which contrasts with the results of Kutzler et al. (2011), 
Table 5. Effects of ractopamine and amino acids on chemical composition and meat quality characteristics in pigs.

\begin{tabular}{|c|c|c|c|c|}
\hline & Control & $\mathrm{RAC}+\mathrm{AA}^{1}$ & $\mathrm{SE}^{2}$ & P-value \\
\hline Dry matter (\%) & 32.94 & 32.16 & 1.10 & 0.174 \\
\hline Crude protein (\%) & 67.78 & 70.08 & 4.00 & 0.269 \\
\hline Ether extract (\%) & 26.17 & 21.39 & 5.11 & 0.082 \\
\hline Drip loss24 (\%) & 4.64 & 3.45 & 2.32 & 0.322 \\
\hline Drip loss48 (\%) & 6.03 & 4.03 & 0.58 & 0.118 \\
\hline Purge loss (\%) & 7.65 & 6.27 & 0.65 & 0.304 \\
\hline $\mathrm{pH}$ & 5.57 & 5.63 & 0.02 & 0.174 \\
\hline Cooking loss (\%) & 31.33 & 40.36 & 3.37 & 0.199 \\
\hline $\mathrm{L}^{*}$ & 58.26 & 60.10 & 0.60 & 0.193 \\
\hline$a^{*}$ & 5.21 & 3.71 & 0.37 & 0.034 \\
\hline$b^{*}$ & 8.16 & 6.33 & 0.36 & 0.055 \\
\hline Hue angle $\left({ }^{\circ}\right)$ & 58.26 & 60.10 & 0.60 & 0.193 \\
\hline Chroma & 9.72 & 7.29 & 0.49 & 0.420 \\
\hline Warner Bratzler Shear ${ }^{3}(\mathrm{~kg})$ & 2.42 & 2.81 & 0.12 & 0.092 \\
\hline
\end{tabular}

${ }^{1} \mathrm{RAC}+\mathrm{AA}$ : contained $10 \mathrm{mg} \mathrm{RAC} \mathrm{kg}{ }^{-1}$ of diet and added amino acids.

${ }^{2}$ Pooled SE from ANOVA.

${ }^{3}$ Warner Bratzler Shear measurements were based on AMSA (1995).

who observed a decreased $L^{*}$ in pork from RAC fed pigs. Contrary to our results, Carr et al. (2005) reported a reduction in $b^{*}$ using 10 and $20 \mathrm{mg}$ RAC kg-1 diets, and Xiong et al. (2006) found no differences in $a^{*}$.

Regarding marbling scores, we did not observe differences between treatments $(P=0.42)$, with a median value of two for both groups. Likewise, Weber et al. (2006) and Athayde et al. (2012) found that subjective marbling scores were not affected by RAC, whereas Aalhus et al. (1990) and Armstrong al. (2004) observed a greater marbling score for RAC animals compared with non-treated animals.

\section{Residues}

The effect of RAC + AA on RAC in liver and muscle are presented in Table 6. Animals were slaughtered approximately 18 hours after the last feeding, and we found an average of $2.45 \pm 0.68$ $\mu \mathrm{g}$ of RAC residues $\mathrm{kg}^{-1}$ in loin samples and 6.79 $\pm 3.29 \mu \mathrm{g}$ of RAC residues $\mathrm{kg}^{-1}$ in liver, which is under the maximum residue limits established by the Codex Alimentarius of $10 \mu \mathrm{g} \mathrm{kg}^{-1}$ and 40 $\mu \mathrm{g} \mathrm{kg}^{-1}$ in muscle and liver, respectively (Codex Alimentarius, 2011). Qiang et al. (2007) fed pigs a diet with $18 \mathrm{mg} \mathrm{kg}^{-1}$ of RAC for 28 days. Animals were killed at days 0, 1, 2, 3, 7, 9 and 14 after withdrawing RAC. At day 0 , an average of $2.58 \mu \mathrm{g} \mathrm{kg}^{-1}$ of RAC was observed in muscle. After day 1, the RAC concentration was below the lower level of detection in muscle, fat and serum. Similarly, Pleadin et al. (2012) observed that RAC concentrations in muscle tissue were below the lower level of detection $(<0.4 \mathrm{mg} \mathrm{kg}$ $\left.{ }^{1}\right)$ and that $7.21 \pm 2.73 \mathrm{ng} \mathrm{RAC} \mathrm{g}^{-1}$ in liver was detected after the first day of treatment interruption when dosing the animals with $0.1 \mathrm{mg} \mathrm{kg}^{-1}$ body weight (compared with approximately 0.3 $\mathrm{mg} \mathrm{kg}{ }^{-1}$ body weight in our study).

Confidence limits (at 90\%) for RAC in muscle and liver were determined to be -2.7 to $3.4 \mu \mathrm{g} \mathrm{kg}^{-1}$ and -6.7 to $10.6 \mu \mathrm{g} \mathrm{kg}^{-1}$, respectively, which are below the maximum limits of $10 \mu \mathrm{g} \mathrm{kg}^{-1}$ for muscle and $40 \mu \mathrm{g} \mathrm{kg}^{-1}$ for liver established by the Codex Alimentarius (Codex Alimentarius, 2011). Moreover, the maximum residues obtained both for muscle 
Table 6. Ractopamine in muscles and liver of pigs fed ractopamine (10 $\mathrm{mg} \mathrm{kg}^{-1}$ diet) and slaughtered 18 hours after withdrawal ${ }^{1,2}$.

\begin{tabular}{|c|c|c|}
\hline & \multicolumn{2}{|c|}{ Ractopamine concentration $\left(\mu \mathrm{g} \mathrm{kg}^{-1}\right)$} \\
\hline & Control & $\mathrm{RAC}+\mathrm{AA}^{3}$ \\
\hline Animal & \multicolumn{2}{|c|}{ 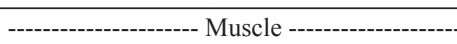 } \\
\hline 1 & ND4 & 2.40 \\
\hline 2 & ND & 2.83 \\
\hline 3 & ND & 1.31 \\
\hline 4 & & 3.08 \\
\hline 5 & & BQL5 \\
\hline 6 & & 2.62 \\
\hline Mean $\left(\mu \mathrm{g} \mathrm{kg}^{-1}\right)$ & - & 2.45 \\
\hline Standard deviation $\left(\mu \mathrm{g} \mathrm{kg}^{-1}\right)$ & - & 0.68 \\
\hline Coefficient of variation (\%) & - & 27.93 \\
\hline Animal & ------------ & ----------------- \\
\hline 1 & ND & 7.70 \\
\hline 2 & ND & 5.70 \\
\hline 3 & ND & 6.44 \\
\hline 4 & & 7.65 \\
\hline 5 & & 11.67 \\
\hline 6 & & 1.55 \\
\hline Mean $\left(\mu \mathrm{g} \mathrm{kg}^{-1}\right)$ & - & 6.79 \\
\hline Standard deviation $\left(\mu \mathrm{g} \mathrm{kg}^{-1}\right)$ & - & 3.29 \\
\hline Coefficient of variation (\%) & - & 48.50 \\
\hline
\end{tabular}

${ }^{1}$ There were 2 treatments with 3 pigs in the control and 6 pigs in the $\mathrm{RAC}+\mathrm{AA}$ fed animals.

${ }^{2} \mathrm{RAC}$ residues were measured using high performance liquid chromatography with tandem mass spectrometry (LC/MS/MS) as described by Blanca et al. (2005).

${ }^{3} \mathrm{RAC}+\mathrm{AA}$ : contained $10 \mathrm{mg} \mathrm{RAC} \mathrm{kg}{ }^{-1}$ of diet and added amino acids. ${ }^{4} \mathrm{ND}$ : not detected

${ }^{5} \mathrm{BQL}$ : Detected, but below quantification limit.

and liver were 69.2 and $70.8 \%$ below the maximum residue limits established by the Codex.

According to the results obtained from this study, supplementation with $\mathrm{RAC}+\mathrm{AA}$ produced most of the desirable effects described in the literature for growth and carcass characteristics, with the exception of dressing and backfat depth. Regarding meat quality characteristics, a tendency was observed for a RAC + AA diet to reduce ether extract, increase Warner Bratzler shear and reduce $a^{*}$ in pork. Finally, residues found in muscle and liver were below Codex Alimentarius limits but higher than other values reported in the literature, which may be because of the higher supplementation dose or shorter withdrawal period prior to slaughter.

According to this study, dietary inclusion of

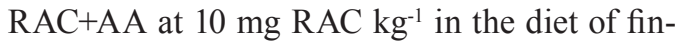
ishing pigs during the last 27 days of finishing produced greater weight gain and feed efficiency. Pigs fed RAC+AA produced heavier carcasses and commercial cuts with minimal effects on meat quality. Finally, RAC residues in muscle and liver were below Codex Alimentarius (2011) limits. 


\section{Resumen}

C.A. Elmes, O.H. Bustamante, F.G. González, R.E. Larraín y M. Gandarillas. 2014. Efecto de la adición de ractopamina y aminoácidos en los parámetros de crecimiento, características de canal, calidad de carne y residuos de cerdos de engorda. Cien. Inv. Agr. 41(3):297-308. El objetivo de este estudio fue medir el efecto de la adición de ractopamina (RAC) y aminoácidos (AA) en la dieta sobre el crecimiento, características de la canal, rendimiento de cortes comerciales, características de la carne y residuos en hígado y músculo. Noventa y dos cerdos castrados $(97,96 \pm 2,32 \mathrm{~kg})$ fueron asignados aleatoriamente a dos dietas: un Control con

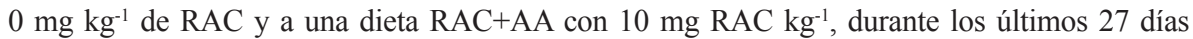
de engorda. Los cerdos RAC+AA tuvieron mayor ganancia diaria de peso (GDP), eficiencia de conversión alimenticia (ECA) y peso final $(\mathrm{P} \leq 0,05)$ y tendieron a comer menos $(\mathrm{P}=0,084)$. Las canales del grupo $\mathrm{RAC}+\mathrm{AA}$ fueron más pesadas $(\mathrm{P} \leq 0,05)$, pero son diferencias en rendimiento $\mathrm{y}$ espesor de grasa dorsal. El peso de cabeza y plancha no fue diferente, pero el grupo RAC+AA tuvo pesos mayores en el lomo de centro, lomo vetado, costillar, pulpa paleta, pulpa pierna, pernil y sobras $(\mathrm{P} \leq 0,05)$. La adición de RAC+AA no afectó la proteína cruda y materia seca del lomo, pero redujo el extracto etéreo $(\mathrm{P}=0,08)$. No hubo diferencia en la pérdida por goteo, y por cocción, ni en $\mathrm{pH}$, pero la fuerza de corte tendió $(\mathrm{P}=0,092)$ a ser mayor en $\mathrm{RAC}+\mathrm{AA}$. No hubo diferencias en $L^{*}$ y $b^{*}$ pero sí en $a^{*}$, siendo más bajo en RAC+AA. El ángulo Hue y Chroma no difirieron. El intervalo de confianza al $90 \%$ determinó que los residuos en músculo e hígado fueron de $-2,7$ a 3,4 $\mathrm{mg} \mathrm{kg}^{-1}$ y $-6,7$ a 10,6 $\mathrm{mg} \mathrm{kg}^{-1}$, respectivamente. La inclusión de RAC+AA en la dieta de cerdos de engorda, produjo canales y cortes comerciales más pesados, con efectos mínimos en características de la carne y con residuos de RAC bajo el límite del Codex Alimentarius.

Palabras clave: Calidad de carne, cerdos de engorda, cortes comerciales, ractopamina, residuos.

\section{References}

Aalhus, J. L., S.D.M. Jones, A.L. Schaefer, A.K.W. Tong, W.M. Robertson, J.K. Merril, and A.C. Murray. 1990. The effect of ractopamine on performance, carcass composition and meat quality of finishing pigs. Can. J. Anim. Sci. 70:943-952.

Agostini, P.S., C.A. Silva, A.M. Bridi, R.A.M. Abrami, G.D. Pacheco, A.P. Lozano, M.S. Ywazaki, D.B. Dalto, D.F. Gavioli, E.R. Oliveira, E.G. Bonafé, N.E. Souza, and J.V. Visentainer. 2011. Efeito da ractopamina na performance e na fisiología do suíno. Arch. Zootec. 60: 659-670.

AMSA-American Meat Science Association. 1995. Research guidelines for cookery, sensory evaluation and instrumental tenderness measurements of fresh meat. National Live Stock and Meat Board, Chicago, Illinois.

Apple, J.K., C.V. Maxwell, D.C. Brown, K.G. Friesen, R.E. Musser, Z.B. Johnson, and T.A. Arm- strong. 2004. Effects of dietary lysine and energy density on performance and carcass characteristics of finishing pigs fed ractopamine. J. Anim. Sci. 82:3277-3287.

Apple, J.K., P.J. Rincker, F.K. McKeith, S.N. Carr, T.A. Armstrong, and P.D. Matzat. 2007. Review: Meta-analysis of the ractopamine response in finishing swine. Prof. Anim. Sci. 23:179-196.

AOAC. 1984. Official Methods of Analysis. 15th edn. Association of Official Analytical Chemists, Arlington, Virginia.

Armstrong, T.A., D.J. Ivers, J.R. Wagner, D.B. Anderson, W.C. Weldon, and E.P. Berg. 2004. The effect of dietary ractopamine concentration and duration of feeding on growth performance, carcass characteristics, and meat quality of finishing pigs. J. Anim. Sci. 82:3245-3253.

Athayde, N.B., O.A. Dalla Costa, R.O. Roça, A.L. Guidoni, C.B. Ludtke, and G.J.M.M. Lima. 2012. Meat quality of swine supplemented with 
ractopamine under commercial conditions in Brazil. J. Anim. Sci. 90:4604-4610.

Barker, M.R., S.S. Dritz, M.D. Tokach, R.D. Goodband, and C.N. Grosebeck. 2005. Effects of ractopamine $\mathrm{HCl}$ on growth performance and within- pen weight variation in finishing pigs. J. Swine. Health. Prod. 13:318-321.

Blanca, J., P. Muñoz, M. Morgado, N. Méndez, A. Aranda, T. Reuvers, and H. Hooghuis. 2005. Determination of clenbuterol, ractopamine and zilpaterol in liver and urine by liquid chromatography tandem mass spectrometry. Anal. Chim. Acta 529:199-205.

Carr, S.N., P.J. Rincker, J. Killefer, D.H. Baker, M. Ellis, and F.K. McKeith. 2005. Effects of different cereal grains and ractopamine hydrochloride on performance, carcass characteristics, and fat quality in late-finishing pigs. J. Anim. Sci. 83:223-230.

Carr, S.N., D.N. Hamilton, K.D. Miller, A.L. Schroeder, D. Fernández-Dueñas, J. Killefer, M. Ellis, and F.K. McKeith. 2009. The effect of ractopamine hydrochloride (Paylean ${ }^{\circledR}$ ) on lean carcass yields and pork quality characteristics of heavy pigs fed normal and amino acid fortified diets. Meat Sci. 81:533-539.

Codex Alimentarius. 2011. Programa conjunto FAO/ OMS sobre normas alimentarias. $34^{\circ}$ Período de sesiones. FAO, WHO, United Nations, Geneva, Switzerland.

Dunshea, F.R., R.H. King, R.G. Campbell, R.D. Sainz, and Y.S. Kim. 1993. Interrelationships between sex and ractopamine on protein and lipid deposition in rapidly growing pigs. J. Anim. Sci. 71: 2919-2930.

Edmonds, M.S., and D.H. Baker. 2010. Effect of dietary protein and lysine fluctuations in the absence and presence of ractopamine on performance and carcass quality of late-finishing pigs. J. Anim. Sci. 88: 604-611.

Fernández-Dueñas, D.M., A.J. Myers, S.M. Scramlin, C.W. Parks, J. Killefer, and F.K. McKeith. 2008. Carcass, meat quality, and sensory characteristics of heavy body weight pigs fed ractopamine hydrochloride (Paylean). J. Anim. Sci. 86:3544-3550.
Groesbeck, C.N., R.D. Goodband, M.D. Tokach, S.S. Dritz, J.L. Nelssen, and J.M. DeRouchey. 2007. Effects of pantothenic acid on growth performance and carcass characteristics of growingfinishing pigs fed diets with or without ractopamine hydrochloride J. Anim. Sci. 85: 2492-2497.

Kutzler, L.W., S.F. Holmer, D.D. Boler, S.N. Carr, M.J. Ritter, C.W. Parks, F.K. McKeith, and J. Killefer. 2011. Comparison of varying doses and durations of ractopamine hydrochloride on latefinishing pig carcass characteristics and meat quality. J. Anim. Sci. 89: 2176-2188.

Luengo, J., and G. Antmann. 1999. Study of cutting techniques and the different cut performed in swine carcasses. Avances en Ciencias Veterinarias $14: 14-33$.

Marchant-Forde, J.N., D.C. Lay Jr., E.A. Pajor, B.T. Richert, and A.P Schinckel. 2003. The effects of ractopamine on the behavior and physiology of finishing pigs. J. Anim. Sci. 81:416-422.

Mimbs, K.J., T.D. Pringle, S.A. Meers, and T.A. Armstrong. 2005. Effects of ractopamine on performance and composition of pigs phenotypically sorted into fat and lean groups. J. Anim. Sci. 83: 1361-1369.

Moody, D.E., D.L. Hancock and D.B. Anderson. 2000. Phenetanolamine Repartioning Agents. In: J.P.F. D’Mello (ed.). Farm Animal Metabolism and Nutrition. CAB International. New York, NY. p. 65-95.

NPPC. 1999. Official color and marbling standards. National Pork Producers Council, Des Moines, IA.

National Research Council. 2012. Nutritional Requirements of Swine. 11th Ed. National Academy Press, Washington, DC.

Pérez, A., N.E. Obispo, J. Palma and C.F. Chicco. 2005. Efectos de la ractopamina y el nivel de lisina sobre la respuesta productiva de cerdos magros en la fase de engorde. Zootecnia Trop. 23: 429-445.

Pleadin, J., N. Perši, A. Vulić, D. Milić, and N. Vahčić. 2012. Determination of residual ractopamine concentrations by enzyme immunoassay in treated pig's tissues on days after withdrawal. Meat. Sci. 90: 755-758. 
Qiang, Z., F. Shentu, B. Wang, J. Wang, J. Chang, and J. Shen. 2007. Residue depletion of ractopamine and its metabolites in swine tissues, urine, and serum. J. Agric. Food. Chem. 55:4319-4326.

Rikard-Bell, C., M.A. Curtis, R.J. van Barneveld, B.P. Mullan, A.C. Edwards, N.J. Gannon, D.J. Henman, P.E. Hughes, and F.R. Dunshea. 2009. Ractopamine hydrochloride improves growth performance and carcass composition in immunocastrated boars, intact boars, and gilts. J. Anim. Sci. 87:3536-3543.

Ross, K.A., A.D. Beaulieu, J. Merrill, G. Vessie, and J.F. Patience. 2011. The impact of ractopamine hydrochloride on growth and metabolism, with special consideration of its role on nitrogen balance and water utilization in pork production. J. Anim. Sci. 89:2243-2256.

SAG-Servicio Agrícola y Ganadero. 2012. Resolución Exenta No 000044 del Servicio Agrícola y Ganadero del 19 de Enero del 2012. Santiago, Chile.

Sakai, T., T. Hitomi, K. Sugaya, S. Kai, M. Murayama, and T. Maitani. 2007. Determination method for ractopamine in swine and cattle tissues using LC/MS. J. Food. Hyg. Soc. 48:144-147.

See, M.T., T.A. Armstrong, and W.C. Weldon. 2004 Effect of a ractopamine feeding program on growth performance and carcass composition in finishing pigs. J. Anim. Sci. 82:2474-2480.

Schinckel, A.P., B.T. Richert, and C.T. Herr. 2002. Ractopamine at one year of commercial application: Variation in the response of multiple genetic population of pigs to ractopamine. J. Anim. Sci. 80:E85-E89.

Schinckel, A.P., N. Li, B.T. Richert, P.V. Preckel, and M.E. Einstein. 2003. Development of a model to describe the compositional growth and dietary lysine requirements of pigs fed ractopamine. J. Anim. Sci. 81:1106-1119.
Shishani, E., S.C. Chai, S. Jamokha, G. Aznar, and M.K. Hoffman. 2003. Determination of ractopamine in animal tissues by liquid chromatography-fluorescence and liquid chromatography/ tandem mass spectrometry. Anal. Chim. Acta 483: $137-145$.

Stoller, G.M., H.N. Zerby, S.J. Moeller, T.J. Baas, C. Johnson, and L.E. Watkins. 2003. The effect of feeding ractopamine (Paylean) on muscle quality and sensory characteristics in three diverse genetic lines of swine. J. Anim. Sci. 81:1508-1516.

Watkins, L.E., D.J. Jones, D.H. Mowrey, D.B. Anderson, and E.L. Veenhuizen. 1990. The effect of various levels of ractopamine hydrochloride on the performance and carcass characteristics of finishing swine. J. Anim. Sci. 68:3588-3595.

Weber, T.E., B.T. Richert, M.A. Belury, Y. Gu, K. Enright, and A.P. Schinckel. 2006. Evaluation of the effects of dietary fat, conjugated linoleic acid, and ractopamine on growth performance, pork quality, and fatty acid profiles in genetically lean gilts. J. Anim. Sci. 84:720-732.

Webster, M.J., R.D. Goodband, M.D. Tokach, J.L. Nelseen, S.S. Dritz, J.A. Unruh, K.R. Brown, D.E. Real, J.M. Derouchey, J.C. Woodworth, C.N. Groesbeck, and T.A. Marsteller. 2007. Interactive effects between ractopamine hydrochloride and dietary lysine on finishing pig growth performance, carcass characteristics, pork quality, and tissue accretion. Prof. Anim. Sci. 23:597-611.

Xiong Y.L., M.J. Gower, C. Li, C.A. Elmore, G.L. Cromwell, and M.D. Lindemann. 2006. Effect of dietary ractopamine on tenderness and postmortem protein degradation of pork muscle. Meat Sci. 73:600-604. 